\title{
МОДЕЛЮВАННЯ ТЕПЛОВИХ РЕАКЦІЙ ЛЮДИНИ ПІД ЧАС ЗАНУРЕННЯ У ТЕПЛУ ВОДУ
}

\author{
І. Й. Єрмакова, Л. Д. Монтгомері ${ }^{1}$, А. Ю. Ніколаєнко, \\ Ю. М. Бондаренко ${ }^{2}$ Н. Г. Іванушкіна ${ }^{3}$ \\ Міжнародний науково-навчальний центр інорормаційних технологій та систем \\ НАН України і МОН України \\ ${ }^{1}$ LDM Associates, США

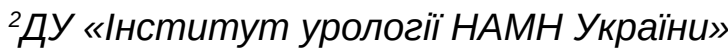 \\ ${ }^{3}$ Національний технічний університет України «Київський політехнічний інститут \\ імені Ігоря Сікорського»
}

\begin{abstract}
У статті наведено математичну модель терморегуляції людини у теплій воді і результати впливу теплої води на людину в умовах спокою та фрізичного навантаження. Розглянуто діапазон занурення у воду від $35^{\circ} \mathrm{C}$ до $38^{\circ} \mathrm{C}$. Модель реалізовано у вигляді зручного для користувача комп'ютерного симулятора. Модель дає прогнози на основі даних про людину, швидкості метаболізму, умов навколишнього середовища та біофрізики одягу. За результатами моделювання зроблено висновок, що занурення людини в теплу воду — це стрімкий, швидкий за часом процес, що вимагає жорсткого контролю. Порівняння результатів моделювання з вимірами на добровольцях підтвердило ці дані. Показано, що динаміка нагріву людини істотно залежить від температури води та часу занурення. Під час короткочасного занурення навіть за високої температури води немає загрози перегрівання людини, однак тривалість занурення може призвести до перегрівання.
\end{abstract}

Ключові слова: біофізика, фрізіологія, терморегуляція, занурення у воду, фрізичне навантаження.

\section{MODELING PREDICTION OF HUMAN THERMAL RESPONSES IN WARM WATER}

\author{
I. J. Yermakova, L. D. Montgomery ${ }^{1}$, A. Yu. Nikolaienko, \\ Yu. M. Bondarenko², N. G. Ivanushkina ${ }^{3}$ \\ International Research-Training Center for Information Technologies and Systems, \\ National Academy of Sciences \\ ${ }^{1}$ LDM Associates, USA \\ IInstitute of Urology, National Academy of Medical Sciences \\ ${ }^{3}$ National Technical University of Ukraine «Igor Sikorsky Kyiv Polytechnic Institute»
}

\begin{abstract}
Background. This paper describes the mathematical model for human thermoregulation in warm water and demonstrates results for impact of warm water immersion in man during resting conditions and exercises. The purpose of the work is to describe a mathematical model of human thermoregulation in warm water and demonstrate the effects of immersion in warm water on a person under conditions of rest and exercise.

Materials and methods. Model is realized as friendly user computer simulator. The model makes prediction based on the human data, metabolic rate, environmental conditions and clothing biophysics.

Results. Modeling resulted in the conclusion that human immersion in warm water is the rapid time process demanding severe control. Comparison of modeling results with measurements in volunteers approved these data. It was demonstrated that dynamics of human heating is highly sensitive to residence time in water. Model predicted main significant effect of human exercises on thermoregulatory responses and human temperatures in different warm water. Physical activity in warm water accelerates the time processes and gains human heating. Additional metabolic heat producing during performance in warm water elevates core temperature significantly.

Conclusions. Modeling showed that steady state depends on human time in water. During short time of immersion even at high water temperature it could be no danger of human overheating, however as human stays in water the danger of overheating become critical.
\end{abstract}

Key words: biophysics, physiology, thermoregulation, water immersion, exercise. 


\title{
МОДЕЛИРОВАНИЕ ТЕПЛОВЫХ РЕАКЦИЙ ЧЕЛОВЕКА ПРИ ПОГРУЖЕНИИ В ТЕПЛУЮ ВОДУ
}

\author{
И. И. Ермакова, Л. Д. Монтгомери ${ }^{1}$ А. Ю. Николаенко, \\ Ю. Н. Бондаренко ${ }^{2}$, Н. Г. Иванушкина ${ }^{3}$ \\ Международный научно-учебный центр инфрормационных технологий и систем \\ НАН Украины и МОН Украины \\ ${ }^{1}$ LDM Associates, CШA

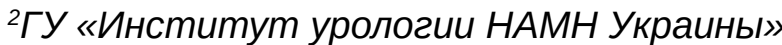 \\ ${ }^{3}$ Национальный технический университет Украины \\ «Киевский политехнический институт имени Игоря Сикорского»
}

\begin{abstract}
В статье представлена математическая модель терморегуляции человека в теплой воде и приведены результаты воздействия теплой воды на человека в условиях покоя и фризической нагрузки. Рассмотрен диапазон погружения в воду от $35^{\circ} \mathrm{C}$ до $38^{\circ} \mathrm{C}$. Модель реализована в виде удобного для пользователя компьютерного симулятора. Модель дает прогнозы на основе данных о человеке, скорости метаболизма, условий окружающей среды и биофизики одежды. По результатам моделирования сделан вывод, что погружение человека в теплую воду — это стремительный, быстрый по времени процесс, требующий жесткого контроля. Сравнение результатов моделирования с измерениями на добровольцах подтвердило эти данные. Показано, что динамика нагрева человека существенно зависит от температуры воды и времени погружения. При кратковременном погружении даже при высокой температуре воды нет угрозы перегрева человека, однако длительность погружения может привести к перегреву.
\end{abstract}

Ключевые слова: биосизика, фризиология, терморегуляция, погружение в воду, фризическая нагрузка.

Introduction. Models for prevention of health risk during immersion. Immersion in water is considered as an extreme challenge for human body. Thermal processes of cooling in cold water or heating in warm water happen rapidly. It is often critical for human health. The main reason of intensive dynamic changes of thermoregulatory processes for human in water is thermal productivity of water that is 25 more than air physical parameter.

The most of modeling researches are directed to study effect of immersion in cold water as it is great risk health [1-7].

Now the interest to learn impact of warm water immersion is motivated in the context of global warming [8]. Military actions, sport events and professional activity demand new view to avoid overheating in warm water. Besides hydrotherapy is used immersion in warm water for healthy people [9].

The practical help to avoid danger for human health in extreme environments is mathematical modeling. It provides preliminary prediction of thermal responses for man. The most of models are related to assessment of hot air environmental conditions [10-12], effect of protective clothing $[13,14]$ and cold air impact in man $[1,15]$ The particular interest and the significance is related to modeling of human water immersion in cold water $[4,5]$.

Theoretical approach is based on use of mathematical empirical [11, 13, 16, 17] and rational models [4, 15] that allow to predict main physiological behavior of man in different environment.
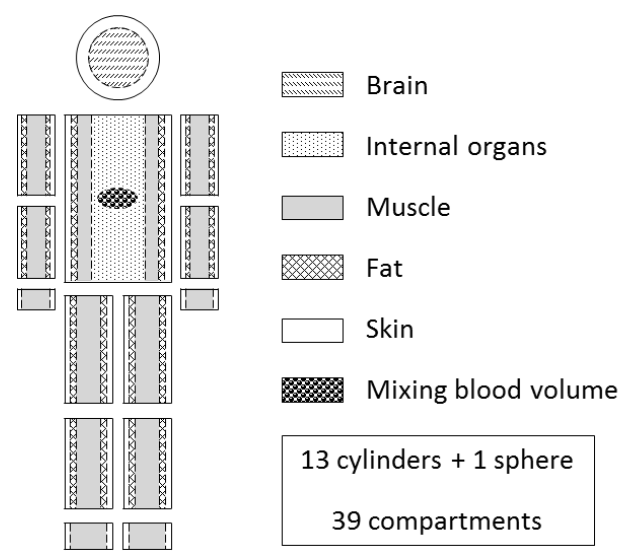

Fig. 1. Model approximation of human body 
Development and application of mathematical models is the one of possible ways to evaluate possible danger during immersion in warm water.

The purpose of the work is to describe a mathematical model of human thermoregulation in warm water and demonstrate the effects of immersion in warm water on a person under conditions of rest and exercise.

Material and methods. Health risk prediction (HRP) model for water immersion.

Mathematical description for metabolic heat production, heat transferring and heat - exchange with environment. Human body is approximated by multilayered cylinders [6]. Every ij-layer (compartment) is related to specific organ of human body. Model accounts for 39 compartments (Fig. 1).

HRP model relies on dynamic heat balance equations to account for exchange between cylinders, water and air environment.

Metabolic heat rate, heat flows transferring by conduction and blood flows inside of human body, effect of water convection on human body, heat-exchange with air environment through convection, radiation and evaporation are based on series of dynamic equations where the general equation is:

$$
\begin{aligned}
& c_{i j} m_{i j} \frac{d T_{i j}}{d t}=M_{i j}+a_{i j-1} \lambda_{i j-1}\left(T_{i j}-T_{i j-1}\right)-a_{i j} \lambda_{i j}\left(T_{i j}-T_{i j+1}\right)- \\
& -\rho_{b} c_{b} w_{i j}\left(T_{i j}-T_{b}\right)-h_{i j}^{C} A_{i j}\left(T_{i j}-T_{i}^{a i r}\right)-h_{i j}^{R} A_{i j}\left(T_{i j}-T_{i}^{a i r}\right)- \\
& -h_{i j}^{E} \cdot A_{i j}\left(P_{i j}-\frac{\varphi_{i}^{a i r}}{100 \%} \cdot P_{i}^{a i r}\right)-\left.h_{i j}^{\text {water }} A_{i j}\left(T_{i j}-T_{i j}^{\text {water }}\right)\right|_{i=\overline{1, N} ; j=\overline{1, K}},
\end{aligned}
$$

where $\mathrm{c}$ - specific heat, $\mathrm{kcal} /\left(\mathrm{kg} \cdot{ }^{\circ} \mathrm{C}\right), \mathrm{m}$ - tissue mass, kg; $\mathrm{T}$ - temperature, ${ }^{\circ} \mathrm{C}$; $\mathrm{t}$ - time, h; $\mathrm{M}-$ metabolic rate, $\mathrm{kcal} / \mathrm{h}$; a - thickness, $\mathrm{m} ; \lambda$-specific heat conductivity, $\mathrm{kcal} /\left(\mathrm{m} \cdot{ }^{\circ} \mathrm{C} \cdot \mathrm{h}\right) ; \rho$ - density, $\mathrm{kg} / \mathrm{m}^{3}$; w-blood flow, $1 / \mathrm{h}$; A - surface area, $\mathrm{m}^{2} ; \mathrm{hC}$ - convection coefficient, $\mathrm{kcal} /\left(\mathrm{m} 2 \cdot{ }^{\circ} \mathrm{C} \cdot \mathrm{h}\right)$; hR - radiation coefficient, $\mathrm{kcal} /\left(\mathrm{m}^{2} \cdot{ }^{\circ} \mathrm{C} \cdot \mathrm{h}\right) ; \mathrm{hE}$ - evaporation coefficient, kcal/ $\left(\mathrm{m}^{2} \cdot \mathrm{kPa} \cdot \mathrm{h}\right) ; \mathrm{P}$ - saturated water vapour pressure, $\mathrm{kPa}$; $\varphi$ - relative humidity, \%; hwater - water convection coefficient, $\mathrm{kcal} /\left(\mathrm{m}^{2} \cdot{ }^{\circ} \mathrm{C} \cdot \mathrm{h}\right)$; indices: $\mathrm{i}$ - body part, $\mathrm{j}$ - layer, b - blood, air - air, water - water, $\mathrm{N}$ - number of body parts, $\mathrm{K}$ - number of layers.

Metabolic heat rate $\left(M^{a}\right)$ during exercise in water is specific to activity level and exercise efficiency during human immersion in water:

$$
M=M^{*}+(1-\eta) \cdot M^{a},
$$

where $M^{*}$ - basal metabolic rate, $\mathrm{kcal} / \mathrm{h} ; M^{a}$ - activity level, $\mathrm{kcal} / \mathrm{h} ; \eta$ - exercise efficiency.

Modeling of water immersion demands additional description of heat exchange of human body and water environment [6].

Water convection is specific to water convection coefficient:

$$
h^{\text {water }}=\lambda^{\text {water }} \cdot N u / d,
$$

where $\lambda^{\text {water }}$ - thermal conductivity of water, kcal/ $\left(\mathrm{m} \cdot{ }^{\circ} \mathrm{C} \cdot \mathrm{h}\right) ; \mathrm{Nu}$ - Nusselt number; $d$ - compartment diameter, $\mathrm{m}$.

Equation for blood temperature is specific to heat flows transferring by blood flows of ij-compartments, cardiac output and respiratory heat loss:

$V_{b} \rho_{b} c_{b} \frac{d T_{b}}{d t}=\sum_{i=1}^{N} \sum_{j=1}^{Z} w_{i j} \rho_{b} c_{b} T_{i j}-W_{b} \rho_{b} c_{b} T_{b}-\bar{V} \rho^{a i r} L^{a i r}\left(y_{e x}-y_{i n}\right)-$

$-\bar{V} \rho^{\text {air }} c^{\text {air }}\left(T_{b}-T^{\text {air }}\right)$,

where $V_{b}$ - blood volume, $\mathrm{l} ; W_{b}$ - cardiac output, l/h; $\bar{V}$ - pulmonary ventilation, l/h; $L$ - specific heat of vaporization, $\mathrm{kcal} / \mathrm{kg} ; y$ - humidity ratio; indices: ex - expired air; in - inspired air.

Thermoregulatory responses in warm water. Thermoregulatory responses account for increase of skin blood flow and sweating.

In model skin blood flow is specific to core body and mean skin temperatures:

$$
W_{s k}=W_{s k}^{*}-S_{1}\left(T_{b r}^{*}-T_{b r}\right)-S_{2}\left(T_{s k}^{*}-T_{s k}\right),
$$

where $W_{\text {sk }}$-skin blood flow, l/h; $S_{1}$ - regulator sensitivity to $T_{b r}$ change, $1 /\left(h \cdot{ }^{\circ} \mathrm{C}\right) ; S_{2}$ - regulator sensitivity to $T_{s k}$ change, $1 /\left(\mathrm{h} \cdot{ }^{\circ} \mathrm{C}\right)$; indices: * - initial value; $b r-$ brain; sk - skin.

Local skin blood flows are specific to relation of ij-compartment surface to total body surface:

$$
w_{i j}=W_{s k} \cdot \frac{A_{i j}}{A},
$$

where $w_{i j}$ - blood flow, 1/h; A -surface of ij compartment, $\mathrm{m}^{2}$.

During immersion in warm water sweating takes place but without regulatory effect as there is no condition to sweat evaporation. Sweat rate is specific to the required evaporation (E) and specific heat of vaporization (L). 


$$
F=\frac{E}{L},
$$

where $F$ - sweat rate, $\mathrm{kg} / \mathrm{h}$; $L$ - specific heat of vaporization, $\mathrm{kcal} / \mathrm{kg}$.

Theoretically required sweat evaporation preventing overheating in warm water is specific to core body and mean skin temperatures:

$$
E=E^{*}-S_{3}\left(T_{b r}^{*}-T_{b r}\right)-S_{4}\left(T_{s k}^{*}-T_{s k}\right), \quad T_{b r} \geq 37.5^{\circ} \mathrm{C},(8)
$$

where $E$ - sweat evaporation, $\mathrm{kcal} / \mathrm{h} ; E^{*}$ - insensible evaporation, $\mathrm{kcal} / \mathrm{h} ; S_{3}$ - regulator sensitivity to $T_{b r}$ change, $\mathrm{kcal} /\left(\mathrm{h} \cdot{ }^{\circ} \mathrm{C}\right) ; S_{4}$ - regulator sensitivity to $T_{s k}$ change, $\mathrm{kcal} /\left(\mathrm{h} \cdot{ }^{\circ} \mathrm{C}\right)$.
Total water losses (WL) are specific to immersion duration:

$$
W L=\int_{0}^{l} F(t) d t,
$$

where $W L$ - water losses, kg; l - duration of residence in water, h.

Input data. Model is realized as friendly user computer simulator. The model makes prediction based on the human data, metabolic rate, environmental conditions and clothing biophysics.

According to purpose of work modeling researches were implemented in the following design.

Modeling was performed for man in rests conditions (standing in water $140 \mathrm{kcal} / \mathrm{h}$ ) and for different levels of physical activity in water (250 kcal/h; $350 \mathrm{kcal} / \mathrm{h}$ ).

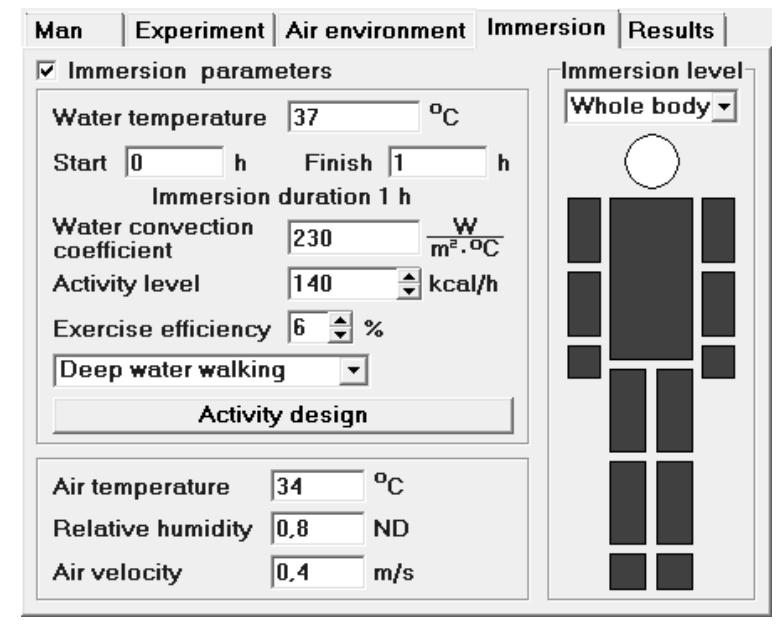

Fig. 2. Computer simulator: input data

Clothing is swimming shorts. Water temperature is $35^{\circ} \mathrm{C}, 36^{\circ} \mathrm{C}, 37^{\circ} \mathrm{C}$ and $38^{\circ} \mathrm{C}$. Duration of immersion is $60 \mathrm{~min}$. Fig. 2 demonstrates screenshot of computer simulator for input data.

Results. Effect of water temperature for human in rest conditions. Model predicted significant effect of water temperature on heating of man during immersion. Human immersion in warm water results in rapid changes of thermoregulatory responses and body temperatures.

Core temperature increases according to the rise of water temperature and residence time. Dynamics of internal organs temperature for man immersed in warm water at temperatures of $35^{\circ} \mathrm{C}, 36^{\circ} \mathrm{C}, 37^{\circ} \mathrm{C}$ and $38{ }^{\circ} \mathrm{C}$ during $60 \mathrm{~min}$ in rest condition is shown in Fig. 3. To the end of exposure internal organs temperature elevated to $+0.09{ }^{\circ} \mathrm{C}$ at $35{ }^{\circ} \mathrm{C},+0.29{ }^{\circ} \mathrm{C}$ at $36{ }^{\circ} \mathrm{C},+0.78^{\circ} \mathrm{C}$ at $37{ }^{\circ} \mathrm{C},+1.53^{\circ} \mathrm{C}$ at $38^{\circ} \mathrm{C}$ of water temperatures.
Internal organs temperature increases during the residence time in water. Transient processes do not finish in $60 \mathrm{~min}$ at $36^{\circ} \mathrm{C}, 37^{\circ} \mathrm{C}, 38^{\circ} \mathrm{C}$ of water temperature. The exception is immersion in water of $35^{\circ} \mathrm{C}$ where it is achieved steady-state to the end of exposure.

Skin temperature follows water temperature sharply. Dynamics of skin temperature in different warm water temperatures is shown in Fig. 4. In all water conditions of human immersion skin temperature is closed to water temperature: $+35.4{ }^{\circ} \mathrm{C}$ at $35^{\circ} \mathrm{C},+36.3^{\circ} \mathrm{C}$ at $36{ }^{\circ} \mathrm{C},+37.0^{\circ} \mathrm{C}$ at $37^{\circ} \mathrm{C},+37.9^{\circ} \mathrm{C}$ at $38^{\circ} \mathrm{C}$ of water conditions.

The main physiological response of thermoregulatory system for human in warm water is the increase of skin blood flow. Thermal response prevents human body from overheating during immersion in warm water. Heat based by skin blood flow performs transfer of core metabolic heat to body surface. 


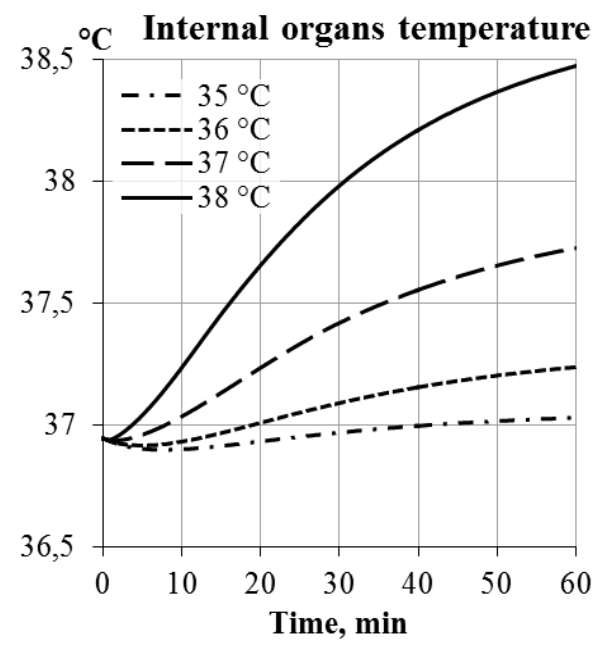

Fig. 3. Dynamics of core temperature during human immersion in warm water of $35^{\circ} \mathrm{C}, 36{ }^{\circ} \mathrm{C}, 37^{\circ} \mathrm{C}$, $38^{\circ} \mathrm{C}$ in rest conditions

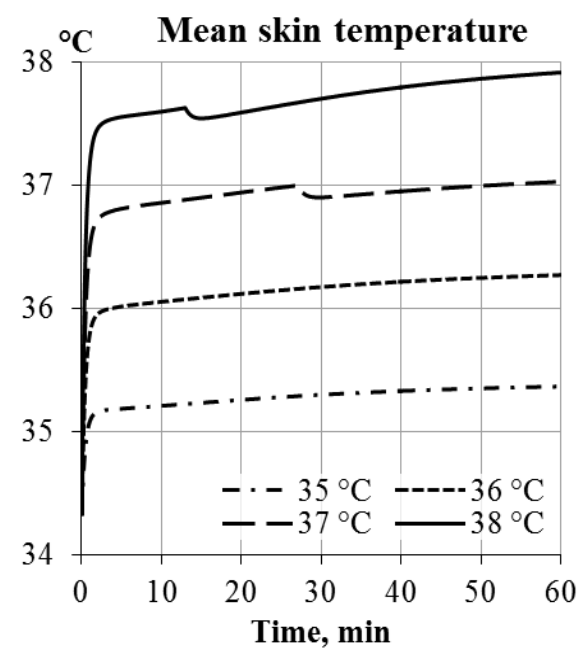

Fig. 4. Dynamics of skin temperature during human immersion in warm water of $35^{\circ} \mathrm{C}, 36{ }^{\circ} \mathrm{C}, 37^{\circ} \mathrm{C}, 38^{\circ} \mathrm{C}$ in rest conditions

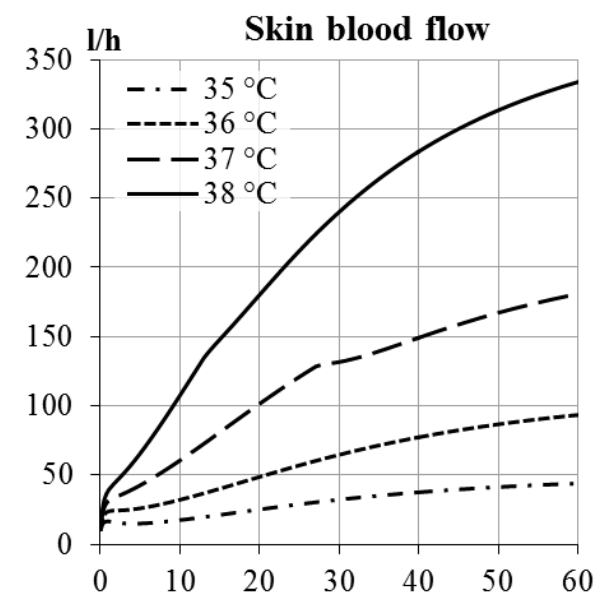

Fig. 5. Dynamics of skin blood flow during human immersion in warm water of $35^{\circ} \mathrm{C}, 36^{\circ} \mathrm{C}, 37^{\circ} \mathrm{C}, 38^{\circ} \mathrm{C}$ in rest conditions 
Fig. 5 shows modeling predictions of skin blood flow for human during immersion at $35^{\circ} \mathrm{C}, 36{ }^{\circ} \mathrm{C}$, $37^{\circ} \mathrm{C}$ and $38{ }^{\circ} \mathrm{C}$ of water temperature. It is resulted in significant change of skin blood flow from $44 \mathrm{l} / \mathrm{h}$ at $35^{\circ} \mathrm{C}, 93 \mathrm{l} / \mathrm{h}$ at $36^{\circ} \mathrm{C}, 181 \mathrm{l} / \mathrm{h}$ at $37^{\circ} \mathrm{C}$ and to $334 \mathrm{l} / \mathrm{h}$ at $38^{\circ} \mathrm{C}$ of water temperatures.

During immersion in warm water sweating takes place too however it does not perform thermoregulatory effect as there are no conditions for sweat evaporation. Dripping sweat over skin depends on water temperature and increases in proportion to elevation of water temperature. Significant water loss takes place during human residence in warm water.

Model predicted total water loss to the end immersion in resting conditions is $88 \mathrm{~g}$ at $35^{\circ} \mathrm{C}, 123 \mathrm{~g}$ at $36^{\circ} \mathrm{C}$, $528 \mathrm{~g}$ at $37^{\circ} \mathrm{C}$ and $1055 \mathrm{~g}$ at $38^{\circ} \mathrm{C}$ (Table 1). Sweat evaporation takes place only from human face as head out of the water. The heat losses are small and equal to13 $\mathrm{kcal} / \mathrm{h}$ at $38^{\circ} \mathrm{C}$.

Water temperature has significant main effect on peak of heart rate. It increases from 84 beats $/ \mathrm{min}$ at $35^{\circ} \mathrm{C}$ to 114 beats $/ \mathrm{min}$ at $38{ }^{\circ} \mathrm{C}$ of water temperature during 60 min of residence in water (Table 1).

Table 1

Heart rate and water losses during human immersion in resting conditions. Time $-60 \mathrm{~min}$

\begin{tabular}{|c|c|c|}
\hline $\mathrm{T}_{\text {water }}$ & $\begin{array}{c}\text { Heart rate, } \\
\text { beats/min }\end{array}$ & Total water losses, $\mathrm{g}$ \\
\hline $35^{\circ} \mathrm{C}$ & 84 & 88 \\
\hline $36^{\circ} \mathrm{C}$ & 88 & 528 \\
\hline $37^{\circ} \mathrm{C}$ & 98 & 1055 \\
\hline $38^{\circ} \mathrm{C}$ & 114 & 123 \\
\hline
\end{tabular}

Human responses in warm water during exercise. Model predicted main significant effect of human exercises on thermoregulatory responses and human temperatures in different warm water. Physical activity in warm water accelerates the time processes and gains human heating. Additional metabolic heat producing during performance in warm water elevates core temperature significantly.

Fig. 6 demonstrates comparative dynamics of core temperature rise for rest conditions and exercises of $250 \mathrm{kcal} / \mathrm{h}, 350 \mathrm{kcal} / \mathrm{h}$ in extremely warm water of $38^{\circ} \mathrm{C}$.

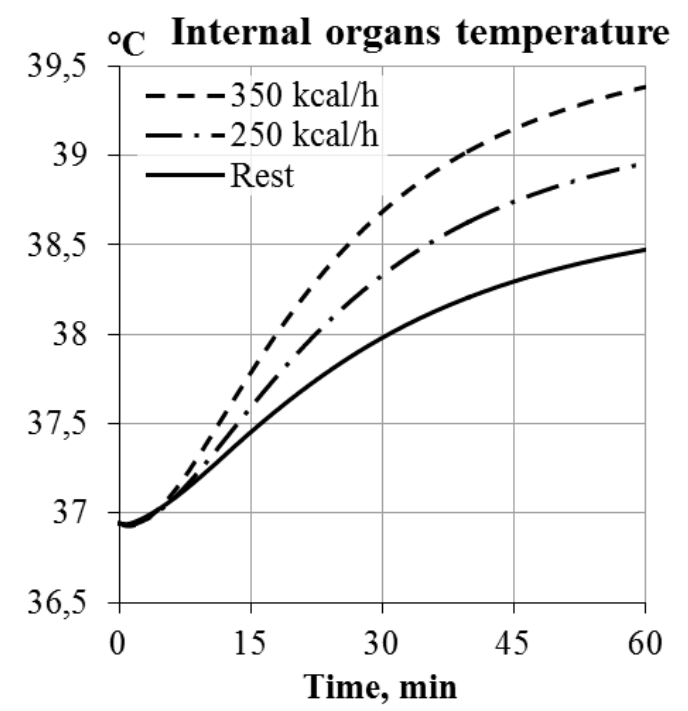

Fig. 6. Effect of human physical activity on core temperature during immersion in water of $38^{\circ} \mathrm{C}$ 
Effect of physical activity $(t=60 \mathrm{~min})$

\begin{tabular}{|c|c|c|c|}
\hline \multirow{3}{*}{$\mathrm{T}_{\text {water }}$} & $\begin{array}{c}\text { Intensity, } \\
\mathrm{kcal} / \mathrm{h}\end{array}$ & $\begin{array}{c}\text { Core } \\
\text { temperature, }{ }^{\circ} \mathrm{C}\end{array}$ & $\Delta \mathrm{T}$ core, ${ }^{\circ} \mathrm{C}$ \\
\hline \multirow{3}{*}{$35^{\circ} \mathrm{C}$} & Rest & 37,03 & $+0,09$ \\
\cline { 2 - 4 } & 250 & 37,33 & $+0,38$ \\
\cline { 2 - 4 } & 350 & 37,65 & $+0,71$ \\
\hline \multirow{3}{*}{$36{ }^{\circ} \mathrm{C}$} & Rest & 37,24 & $+0,29$ \\
\cline { 2 - 4 } & 250 & 37,68 & $+0,74$ \\
\hline \multirow{3}{*}{$37^{\circ} \mathrm{C}$} & 350 & 38,05 & $+1,11$ \\
\cline { 2 - 4 } & Rest & 37,72 & $+0,78$ \\
\cline { 2 - 4 } & 250 & 38,22 & $+1,28$ \\
\hline \multirow{3}{*}{$38^{\circ} \mathrm{C}$} & 350 & 38,64 & $+1,70$ \\
\cline { 2 - 4 } & Rest & 38,47 & $+2,01$ \\
\cline { 2 - 4 } & 250 & 38,96 & $+2,44$ \\
\hline
\end{tabular}

Table 2 presents modeling data for increase of core temperatures during physical activity in different water conditions. It is shown significant effect of physical activity and its level on elevation of core temperature during immersion time.

Table 2 


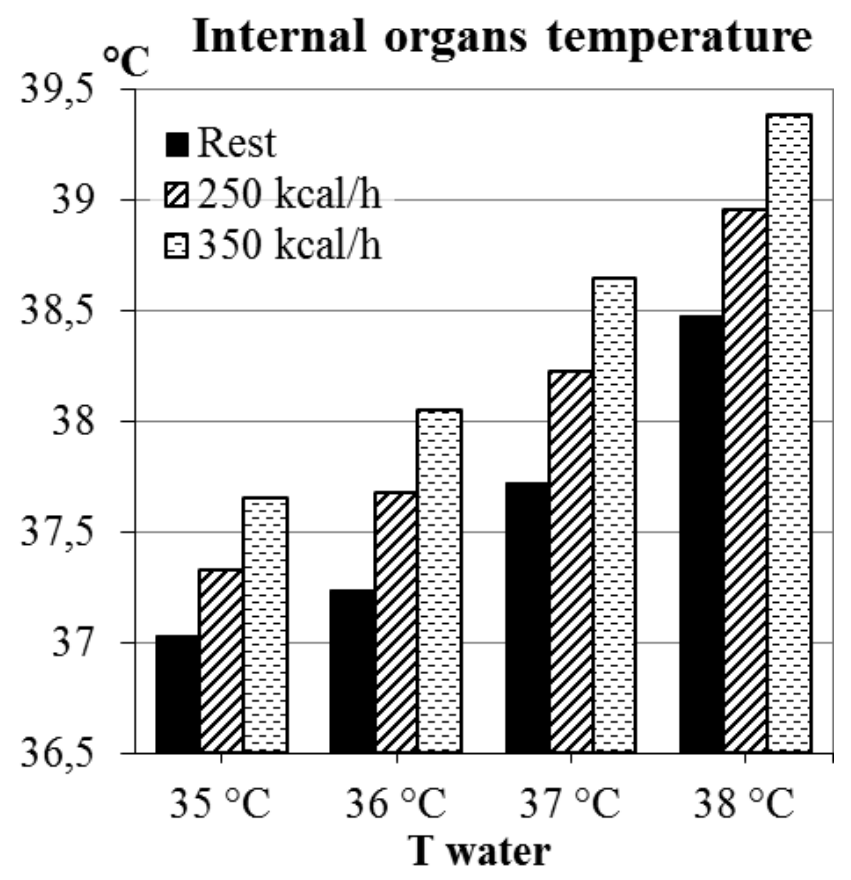

Fig. 8. Internal organs temperatures in different water conditions and different activity level. Immersion time is 60 min

Conclusions and discussion. Modeling resulted in the conclusion that human immersion in warm water is the rapid time process demanding severe control. Comparison of modeling results with measurements in volunteers approved these data [18].

First: human temperature is highly sensitive to water conditions and small rise of water temperature effects on elevation of body temperature.

Second: physical activity in water amplifies transient and steady state processes. Fig. 8 demonstrates human

\section{Література.}

1. Evaluation of two cold thermoregulatory models for prediction of core temperature during exercise in cold water / Castellani J. W., O’Brien C. A., Tikuisis P., Sils I. V., Xu X.// Journal of Applied Physiology. - 2007.Vol. 103. - P. 2034-2041.

2. Cold Stress Effects on Exposure Tolerance and Exercise Performance / Castellani J. W., Tipton M. J. // Comprehensive Physiology. - 2015. - Vol. 6, No 1. P. 443-469.

3. Cold water immersion: kill or cure? / Tipton M. J., Collier N., Massey H., Corbett J., Harper M. // Experimental physiology. - 2017. - Vol. 102, No 11. P. 1335-1355.

4. A model of heat transfer in immersed man / Montgomery L. D. //Annals of Biomedical Engineering.1974. - Vol. 2, No 1. - P. 19-46. temperature evaluation depending on water conditions and activity level in water.

It was demonstrated that dynamics of human heating is high sensitive to residence time in water. Modeling showed that steady state depends on human time in water. During short time of immersion even at high water temperature it could be not danger of human overheating, however as human stays in water the danger of overheating become critical.

5. Effect of ambient temperature on the thermal profile of the human forearm, hand, and fingers / Montgomery L. D., Williams B. A. // Annals of Biomedical Engineering. - 1976. - Vol. 4, No 3. P. 209-219.

6. Predictive Simulation of Physiological Responses for Swimmers in Cold Water / Yermakova I., Montgomery L. // Electronics and nanotechnology (ELNANO) : Proceedings of the IEEE 38th International scientific conference, Kyiv, 24-26 April 2018. - Kyiv, 2018. P. 292-297.

7. Modelling of human cooling in cold water: effect of immersion level / Yermakova I., Nikolaienko A., Solopchuk Y., Regan M. // Extreme Physiology \& Medicine. - 2015. - No 4 (Suppl 1). - P. A132. 
8. Lim C. L. Fundamental Concepts of Human Thermoregulation and Adaptation to Heat: A Review in the Context of Global Warming / Lim C. L. // International Journal of Environmental Research and Public Health. - 2020. - Vol. 17, No 21. - P. 7795.

9. The thermal effects of water immersion on health outcomes: an integrative review / An J., Lee I., Yi Y. // International Journal of Environmental Research and Public Health. - 2019. - Vol. 16, No 7. - P. 1280.

10. Expanded prediction equations of human sweat loss and water needs / Gonzalez R. R., Cheuvront S. N., Montain S. J., Goodman D. A., Blanchard L. A., Berglund L. G., Sawka M. N. // Journal of Applied Physiology. - 2009. - Vol. 107. - P. 379-388.

11. Mathematical prediction of core body temperature from environment, activity, and clothing: the heat strain decision aid (HSDA) / Potter A. W., Blanchard L. A., Friedl K. E., Cadarette B. S., Hoyt R. W. // Journal of Thermal Biology. - 2017. - Vol. 64. - P. 78-85.

12. Computer prediction of human thermoregulatory and temperature responses to a wide range of environmental conditions / Fiala D., Lomas K. J., Stohrer M. // International Journal of Biometeorology. - 2001. Vol. 45, No 3. - P. 143-159.

13. Heat Strain Decision Aid (HSDA) accurately predicts individual-based core body temperature rise while wearing chemical protective clothing / Potter A. W., Hunt A. P., Cadarette B. S., Fogarty A., Srinivasan S., Santee W. R., Blanchard L. A., Looney D. P. // Computers in Biology and Medicine. - 2019. Vol. 107. - P. 131-136.

14. Comparison of Human Respnses to Prototype and Standard Uniforms Using Three Differnet Human Simulation Models: HSDA, Scenario_J and Simulink2NM / Berglund L. G., Yokota M. USARIEM Technical Report T05-08. ADA438017, 2005. - 96 p.

15. Thermoregulatory modeling for cold stress / $\mathrm{Xu} \mathrm{X}$., Tikuisis P. // Comprehensive Physiology. - 2014. Vol. 4, No 3. - P. 1057-1081.

16. Comparison of two mathematical models for predicted human thermal responses to hot and humid environments / Potter A. W., Yermakova I. I., Hunt A. P., Hancock J. W., Oliveira A. V. M., Looney D. P., Montgomery L. D. // Journal of Thermal Biology. 2021. - Vol. 97. - P. 102902.

17. Modeling Thermoregulatory Responses to Cold Environments. Autonomic Nervous System Monitoring / Potter A., Looney D., Xu X., Santee W., Srinivasan S. - Heart Rate Variability. IntechOpen, 2018.

18. Divers risk accelerated fatigue and core temperature rise during fully-immersed exercise in warmer water temperature extremes / Looney D. P., Long E. T., Potter A. W., Xu X., Friedl K. E., Hoyt R. W., Chalmers C. R., Buller M. J., Florian J. P.//Temperature.2019. - Vol. 6, No 2. - P. 150-157.

\section{References.}

1. Castellani, J., O’Brien, C. A., Tikuisis, P., Sils, I. V., $\mathrm{Xu}, \mathrm{X}$. (2007). Evaluation of two cold thermoregulatory models for prediction of core temperature during exercise in cold water. Journal of Applied Physiology, vol. 103, 2034-2041. DOI: 10.1152/japplphysiol.00499.2007.

2. Castellani, J. W., Tipton, M. J. (2015). Cold Stress Effects on Exposure Tolerance and Exercise Performance. Compr Physiol. 6 (1), 443-69. DOI: 10.1002/cphy. c140081.

3. Tipton, M. J., Collier, N., Massey, H., Corbett, J., Harper, M. (2017). Cold water immersion: kill or cure? Experimental physiology, 102 (11), 1335-1355.

4. Montgomery, L. D. (1974). A model of heat transfer in immersed man. Annals of Biomedical Engineering, vol. 2, no. 1, 19-46. DOI: 10.1007/BF02368084.

5. Montgomery, L. D., Williams, B. A. (1976). Effect of ambient temperature on the thermal profile of the human forearm, hand, and fingers. Annals of Biomedical Engineering, vol. 4, no. 3, 209-219. DOI: 10.1007/ BF02584515.

6. Yermakova, I., Montgomery, L. (2018). Predictive Simulation of Physiological Responses for Swimmers in Cold Water. IEEE 38th International scientific conference electronics and nanotechnology (ELNANO), 24-26 April 2018, Kyiv, Ukraine, 292297. DOI: 10.1109/ELNANO.2018.8477523.

7. Yermakova, I., Nikolaienko, A., Solopchuk, Y., Regan, M. (2015). Modelling of human cooling in cold water: effect of immersion level. Extreme Physiology \& Medicine, no. 4 (Suppl 1), A132. DOI: 10.1186/20467648-4-S1-A132.

8. Lim, C.L. (2020). Fundamental Concepts of Human Thermoregulation and Adaptation to Heat: A Review in the Context of Global Warming. International Journal of Environmental Research and Public Health, vol. 17, no 21, 7795. DOI: 10.3390/ijerph17217795.

9. An, J., Lee, I., Yi, Y. (2019). The thermal effects of water immersion on health outcomes: an integrative review. International Journal of Environmental Research and Public Health, vol. 16, no. 7, 1280. DOI: 10.3390/ ijerph16071280.

10. Gonzalez, R. R., Cheuvront, S. N., Montain, S. J., Goodman, D. A. et al. (2009). Expanded prediction equations of human sweat loss and water needs. Journal of Applied Physiology, vol. 107, 379-388. DOI: 10.1152/japplphysiol.00089.2009.

11. Potter, A. W., Blanchard, L. A., Friedl, K. E. et al. (2017). Mathematical prediction of core body temperature from environment, activity, and clothing: the heat strain decision aid (HSDA). Journal of Thermal Biology, vol. 64, 78-85. DOI: 10.1016/j.jtherbio.2017.01.003.

12. Fiala, D., Lomas, K. J., Stohrer, M. (2001). Computer prediction of human thermoregulatory and temperature responses to a wide range of environmental conditions. International Journal of Biometeorology, vol. 45, no. 3, 143-159. DOI: 10.1007/s004840100099. 
13. Potter, A. W., Hunt, A. P., Cadarette, B. S., Fogarty, A. et al. (2019). Heat Strain Decision Aid (HSDA) accurately predicts individual-based core body temperature rise while wearing chemical protective clothing. Computers in Biology and Medicine, vol. 107, 131-136. DOI: 10.1016/j.compbiomed.2019.02.004.

14. Berglund, L. G., Yokota, M. (2005). Comparison of Human Respnses to Prototype and Standard Uniforms Using Three Differnet Human Simulation Models: HSDA, Scenario_J and Simulink2NM. USARIEM Technical Report T05-08. ADA438017. https://apps. dtic.mil/sti/citations/ADA438017.

15. Xu, X., Tikuisis, P. (2014). Thermoregulatory modeling for cold stress. Comprehensive Physiology, vol. 4, no. 3, 1057-1081. DOI: 10.1002/cphy.c130047.

16. Potter, A. W., Yermakova, I. I., Hunt, A. P. et al. (2021) Comparison of two mathematical models for predicted human thermal responses to hot and humid environments. Journal of Thermal Biology, vol. 97, 102902. DOI: 10.1016/j.jtherbio.2021.102902.
17. Potter, A., Looney, D., Xu, X., Santee, W., Srinivasan, S. (2018). Modeling Thermoregulatory Responses to Cold Environments. Autonomic Nervous System Monitoring - Heart Rate Variability. IntechOpen. DOI: 10.5772/intechopen.81238.

18. Looney, D. P., Long, E. T., Potter, A. W., Xu, X. et al. (2019). Divers risk accelerated fatigue and core temperature rise during fully-immersed exercise in warmer water temperature extremes. Temperature, vol. 6, no 2, 150-157. DOI: 10.1080/23328940.2019.1 599182. 